\title{
Heavy Metal Contamination and Mobility at the Mine Area of Draa Lasfar (Morocco)
}

\author{
Marta Avila ${ }^{1}$, Gustavo Perez ${ }^{1}$, Mouhsine Esshaimi ${ }^{2}$, Laila Mandi ${ }^{2,3}$, Naaila Ouazzani ${ }^{2}$, \\ Jose L. Brianso ${ }^{4}$ and Manuel Valiente ${ }^{*}, 1$ \\ ${ }^{1}$ Centre GTS. Chemistry Department, Universitat Autonoma de Barcelona, 08193, Spain \\ ${ }^{2}$ Laboratoire d'Hydrobiologie, Ecotoxicologie et Assainissement (LHEA), Unité associée au CNRST/ URAC 33), Faculté \\ des Sciences Semlalia, Université Cadi Ayyad, Marrakech (Morocco) \\ ${ }^{3}$ National Center for Studies and Research on Water and Energy, University Cadi Ayyad, BP511, 40000 Marrakech \\ (Morocco) \\ ${ }^{4}$ Geology Department, Universitat Autònoma de Barcelona, Spain
}

\begin{abstract}
The present study represents a first insight into the Draa Lasfar mine (Marrakech) to assess the possible diffusion of heavy metals and to predict the risk of their mobility in the surroundings of the mine area. The edaphologic parameters $\mathrm{pH}$, electrical conductivity (EC), loss on ignition (LOI) and $\mathrm{CaCO}_{3}$ were measured according to standard methods, whilst heavy metals concentration was determined by FP-XRF. Concentration enrichment ratios (CER) were calculated in order to estimate the anthropogenic contribution of target pollutants determining $\mathrm{As}, \mathrm{Cu}, \mathrm{Pb}$ and $\mathrm{Zn}$ as the main pollutants, whereas $\mathrm{Ba}, \mathrm{Ca}, \mathrm{Fe}, \mathrm{K}, \mathrm{Mn}, \mathrm{Rb}, \mathrm{Sr}$, Ti and $\mathrm{Zr}$ were considered lithogenic components. GIS contour maps of pollutants using CER data, showed the most polluted areas at the vicinity of the mine, especially at the northwest area, probably linked to weathering effects and topography of the area. Particle size studies revealed that As, $\mathrm{Pb}$ and $\mathrm{Zn}$ are part of the mineral ore while $\mathrm{Cu}$ behavior corresponded to an anthropogenic origin. Additionally, mobility assays employing single leaching tests indicated a greater mobility of $\mathrm{As}$ and $\mathrm{Zn}$ rather than that of $\mathrm{Pb}$ and $\mathrm{Cu}$ due to their lower adsorption process in the soil, independently of their respective concentration.
\end{abstract}

Keywords: Morocco abandon mine pollution, Draa Lasfar mine, toxic metals, risk assessment, GIS, CER evaluation.

\section{INTRODUCTION}

The presence of heavy metals in soils cause considerable impact on the environment causing damages to microflora, flora and fauna, and thus restricting soil use [1]. As a consequence of mining and mineral processing huge amounts of heavy metals are deposited in waste dumps and tailings requiring a management and monitoring once the activity has stopped [2]. In Marrakech region, mining activity represent a high area of activity thus constituting a great hazard due to the presence of high amounts of heavy metals related to functioning or abandoned mines. In this concern, few studies have been done in this area to determine the heavy metal concentration around mine areas and their impact on surrounding soil and water resources [3]. In addition, no detailed investigation has been carried out in the region to assess the potential mobility of heavy metals in order to predict the toxicological risk in the surroundings of Draa Lasfar mine area.

In the last years the systematic control of contaminated areas has become a key issue to define healthcare policies, cost effective environmental planning and risk assessment

*Address correspondence to this author at the Centre GTS. Chemistry Department, Universitat Autonoma de Barcelona, 08193 Spain; Tel: +34935812903; Fax: +34-935811985; E-mail: Manuel.Valiente@uab.es tools [4]. To this purpose Field Portable X-Ray Fluorescence (FP-XRF) equipments have been applied given their reliable and rapid heavy metal measurement which allows to quickly delineate in situ metal contamination at a screening level $[5$, 6]. In addition, high volume of field test can be monitored to determine the spatial distribution and degree of heterogeneity of heavy metals in an undisturbed position while offsite analytical costs are minimized without destruction of the samples $[7,8]$. FP-XRF results can be applied together with Geographic Information Systems (GIS) to determine spatial variability in a mine area. Such tools let to produce maps which are helpful in identifying the sources and spatial patterns of the pollutants [9-11].

Moreover, concentration enrichment ratios (CER), also called enrichment factors, have been used to obtain complementary reliable information concerning site risk assessment $[12,13]$. CER was a concept developed in the early seventies to derive the origin of elements in the atmosphere, precipitation or seawater, and was progressively applied to other environmental materials, such as lake sediments or soils [14]. In many cases, it was used to determine the contribution of anthropogenic emissions to trace element fluxes [15] (Table 1).

Besides the concentration, toxicity and impact of heavy metals in soils and sediments is mostly determined by its mobility and availability [16]. The fate and transfer of these metals is a complex process that depends on the soil minera- 
logy as well as to physico-chemical transport processes. Over the last 30 years, sequential extraction schemes (SES) have been the main tools employed to evaluate the availability of the contaminants in soils, sediments and sludge [1720]. SES represent a chemical scheme which tries to mimic the various natural conditions under which soils may release metals into the water resources thereby providing an indication of the potential bioavailability of those metals. On the other hand, leaching tests such as $\left(\mathrm{NH}_{4}\right)_{2} \mathrm{SO}_{4}$ or $\mathrm{HCl}$ single non-selective extractions methods can provide also a useful assessment to identify labile or mobile phases [21, 22]. The main advantages of these single leaching tests against SES are mainly related to their cost efficiency, easy to use and a reduction on bias induced by sequential translation and accumulation of procedural errors.

Table 1. Anthropogenic Contribution at Different CER Values

\begin{tabular}{|c|c|}
\hline CER & Anthropogenic Contribution \\
\hline \hline$<2$ & Minimal or nule \\
\hline $2-5$ & Moderate \\
\hline $5-20$ & Significant \\
\hline $20-40$ & Strong \\
\hline$>40$ & Extreme \\
\hline
\end{tabular}

In this sense, the main aims of the present study focuses on (i) a geochemical characterization of the Draa Lasfar mine area in order to identify pollutants and lithogenic components present in the soils affected by the mining activity; (ii) the generation of distribution maps of pollutants at the mine area, (iii) the evaluation of particle size effects, such as intraparticle concentration affecting metals distribution and (iv) the assessment of the pollutants mobility employing single leaching tests.

\section{MATERIALS AND METHODOLOGY}

\section{Site Description}

Draa Lasfar mine is located a few hundred meters from the Tensift River, close to a rural community of about 5790 ha of which $65 \%$ are occupied by farmland. The climate is Mediterranean, bordering arid and semi arid with an average annual precipitation of $231 \mathrm{~mm}$ (10 years). Temperatures are characterized by great daily and seasonal variation with an average value of $11.5 \mathrm{C}$ in January and $28.8 \mathrm{C}$ in July. Draa Lasfar mine, involves a deposit of pyrite mineral located 10 $\mathrm{km}$ west of Marrakech city (Fig. 1) that can pose a risk for the environment due to discharge of tailings all around the mine area. Draa Lasfar was discovered in 1953 although their commercial exploitation did not begin until 1979. Mineral was processed by flotation after primary and secondary crushing and grinding producing 59516 tons of products in the first two years (1979-1980) [23]. The Draa Lasfar deposit contains $10 \mathrm{Mt}$ of ore grading $5.3 \mathrm{wt} . \% \mathrm{Zn}, 2$ wt.\% $\mathrm{Pb}, 0.3$ wt.\% $\mathrm{Cu}(2007)$ and their orebodies consist dominantly of pyrrhotite (70 to 95 vol.\% of sulphides, but commonly up to 90 to 95 vol.\% in $\mathrm{Zn}$ and $\mathrm{Cu}$-depleted zones), with lesser sphalerite ( 1 to $10 \mathrm{vol} \%$ ), galena ( 0.5 to 5 vol.\%) and chalcopyrite (1 to 5 vol.\%), and with local concentrations of deformed pyrite ( 2 to 3 vol.\% of total sulphides) being arsenopyrite the most common of the minor

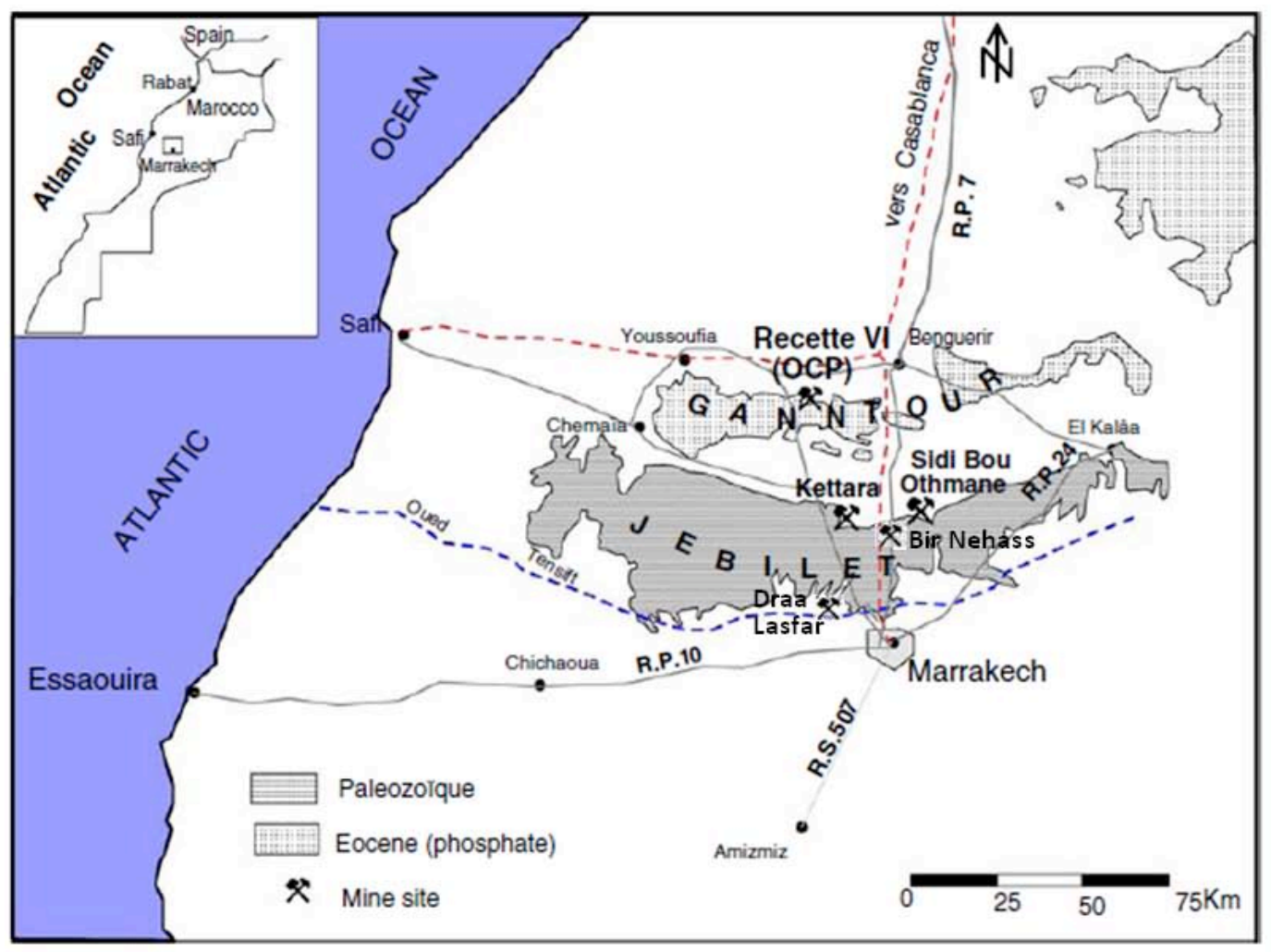

Fig. (1). Location of Draa Lasfar mine. 
minerals [24]. Industrial activity stopped in March 1981, although activity restarted in 1999 due to its great resource of poly-metallic components ( $\mathrm{As}, \mathrm{Cd}, \mathrm{Cu}, \mathrm{Fe}, \mathrm{Pb}, \mathrm{Zn}$ ).

\section{Sampling Description}

In order to assess the impact of the Draa Lasfar mine on the surrounding environment, a total of 85 samples were collected in the vicinity of the mine covering 230 ha through 8 sampling lines oriented towards specific receptor media (Tensift river creek, Koudiyat Tazakourt hill, village, farms, etc.). Two samples were taken at the other side of Tensift river creek (samples 21 and 22) and 4 representative background samples (from 82 to 85 ) at $1 \mathrm{~km}$ from the mining site in order to avoid mining contamination.

Samples were taken every 50 meters from the upper 20 $\mathrm{cm}$ after removing the first layer of surface soil $(2 \mathrm{~cm})$ within an area of $100 \mathrm{~cm}^{2}$. Collected samples were air-dried at $30 \mathrm{C}$ during 48 hours, sieved to remove large debris through a $2 \mathrm{~mm}$ stainless steel sieve and stored in plastic bottles for their transportation to the laboratory.

\section{Sample Analysis and Data Treatment}

The physical characterization consisted in the determination of the soil $\mathrm{pH}$, the electrical conductivity (EC), the loss on ignition (LOI) and the carbonate content of the samples according to standard methods [25]. The $\mathrm{pH}$ was measured in a soil suspension $(2 \mathrm{~g} / 5 \mathrm{ml}$ of distilled water stirred vigorously) after $2 \mathrm{~h}$ of deposition using a $\mathrm{pH}$-meter (Model WTW Multiline P4 Universal pH-meter cabled Sen-Tix 92T $\mathrm{pH}$ electrode, Germany). EC was determined in a soil saturated paste $(1 \mathrm{~g} / 5 \mathrm{ml}$ of distilled water) with a conductometer (Model WTW Multiline P4 Universal Standard Conductivity Cell TetraCon ${ }^{\circledR} 325$, Germany), once corrected to the working temperature $(20 \mathrm{C})$. LOI was determined gravimetrically after volatilization of organic matter on a furnace at $550^{\circ} \mathrm{C}$ during $4 \mathrm{~h}$. For the total carbonate content three replicates of each soil were stirred during $6 \mathrm{~h}$ in an $\mathrm{HCl} 4$ $\mathrm{mol} / \mathrm{L}$ solution $(1.0 \mathrm{~g}$ of soil per $20 \mathrm{ml}$ of $\mathrm{HCl} 4.0 \mathrm{~mol} / \mathrm{L}$ solution) and, after filtering, calcium was measured by flame spectroscopy (Model JENWAY-PFP7, UK). For the chemical characterization, an aliquot of each sample was encapsulated and covered with Mylar ${ }^{\mathbb{R}}$ film prior to their analysis with FP-XRF equipment (Innov-X Systems, model Alpha6500R, Woburn, MA, USA). A soil standard NIST 2710 and a $\mathrm{SiO}_{2}$ blank were measured for corrections and three replicates were measured for each sample. The most contaminated samples were selected for the particle size effect and mobility assays studies. For the particle size effect studies, samples were milled and sieved below $100 \mu \mathrm{m}$ for analysis of the fraction below $100 \mu \mathrm{m}$ by FP-XRF. Mobility assays were performed by applying a established methodology [26] consisting on sample extraction with $\mathrm{HCl} 0.5 \mathrm{M}$ during $1 \mathrm{~h}$ under magnetic stirring. After each extraction, the suspension was centrifuged and the supernatant was filtered using $0.22 \mu \mathrm{m}$ filters (Millex GS, Millipore, Ireland). The extracts were analyzed by means of Inductively Coupled Plasma-Optical Emission Spectroscopy (ICP-OES) (Thermo Elemental model Intrepid II XLS, Franklyn, MA, USA).

CER indicators were calculated considering the concentration of a given element, namely $\mathrm{Cn}$, in both target and background samples, normalized with respect to a lithogenic conservative element such as $\mathrm{Al}, \mathrm{Zr}$ or $\mathrm{Ti}$, which is accurately determined in each sample (see expression 1). Rubio et al. [12] recommended the use of regional background values. While the geochemical background values are constant, the levels of contamination vary with time and places. Background values are distinctly different among different soil types, especially with respect to $\mathrm{Na}, \mathrm{Mg}, \mathrm{Al}, \mathrm{K}$, $\mathrm{Ca}, \mathrm{Ba}, \mathrm{Sc}, \mathrm{Ti}, \mathrm{Fe}$ and $\mathrm{Zr}$ [13]. Zr was selected as lithogenic element due to homogeneity of $\mathrm{Zr}$ concentration in all samples and backgrounds.

$$
\operatorname{CER}_{\mathrm{n}}=\frac{\left(\mathrm{C}_{\mathrm{n}} / \mathrm{C}_{\mathrm{n} \text { Background }}\right)}{\left(\mathrm{C}_{\mathrm{Zr}} / \mathrm{C}_{\mathrm{Zr} \mathrm{Background}}\right)}
$$

The evaluation of the extent and distribution of contamination was carried out by using Geographic Information Systems (GIS) [27-29] which in addition, allowed the detection of the areas requiring monitoring or even treatment. GIS maps for the distribution of target metals around the mine area were done by Miramon v6.4 - Complete Geographical Information System and Remote Sensing software [30]. Different interpolation methods can be used to determine spatial variability such as inverse distance weighting (IDW), Kriging and spline functions [31]. While spline method involve a considerable interpolation error when there are large changes in the surface values within a short horizontal distance, kriging method may not be met in practice unless employing 100 samples in order to obtain a reliable variogram that correctly describes spatial structure. In contrast, IDW interpolator assumes that each input point has a local influence that diminishes with distance [32], and no assumptions are required for the data, being this method the most suitable for our irregular sampling [33].

\section{RESULTS AND DISCUSSION}

$\mathrm{pH}$, LOI and carbonate content [34] are geochemical soil characteristics able to provide sufficient information to understand the soils capacity to retain heavy metal pollutants. (Numerical values on $\mathrm{pH}, \mathrm{EC}, \mathrm{LOI}$ and $\mathrm{CaCO} 3$ for each sample can be found on Table S1 of Supplementary material). Results obtained for the soil $\mathrm{pH}$ measurements, depicted in GIS (Fig. 2) revealed that, in general, all sampled points presented a neutral to alkaline $\mathrm{pH}$ ranging from 7 to 9 , similar to background samples with the exception of a very acidic sample corresponding to sample D48 with a $\mathrm{pH} 3.47$. $\mathrm{pH}$ variations indicate to be related to heterogeneous deposits of sulfidic residues at the surroundings of the mine which can cause a decrease of the $\mathrm{pH}$ by corresponding oxidation and formation of sulfuric acid. EC showed more variability than the $\mathrm{pH}$, with $\mathrm{EC}$ values ranging from 100 to $15.000 \mu \mathrm{S} / \mathrm{cm}$ (Fig. 3). In general, these results are correlated with previous studies carried on Morocco soils [35]. A decreasing salinity gradient was also observed and the values obtained for the mine area samples are significantly higher than for the background samples which indicate high amounts of labile ions close to the mine area. A hot spot located at sample D31 with an EC of $14.160 \mu \mathrm{S} / \mathrm{cm}$ was observed mainly due to high amounts of metals present in this area. LOI values of the mine area and background samples (Fig. 4) have similar values, ranging from 


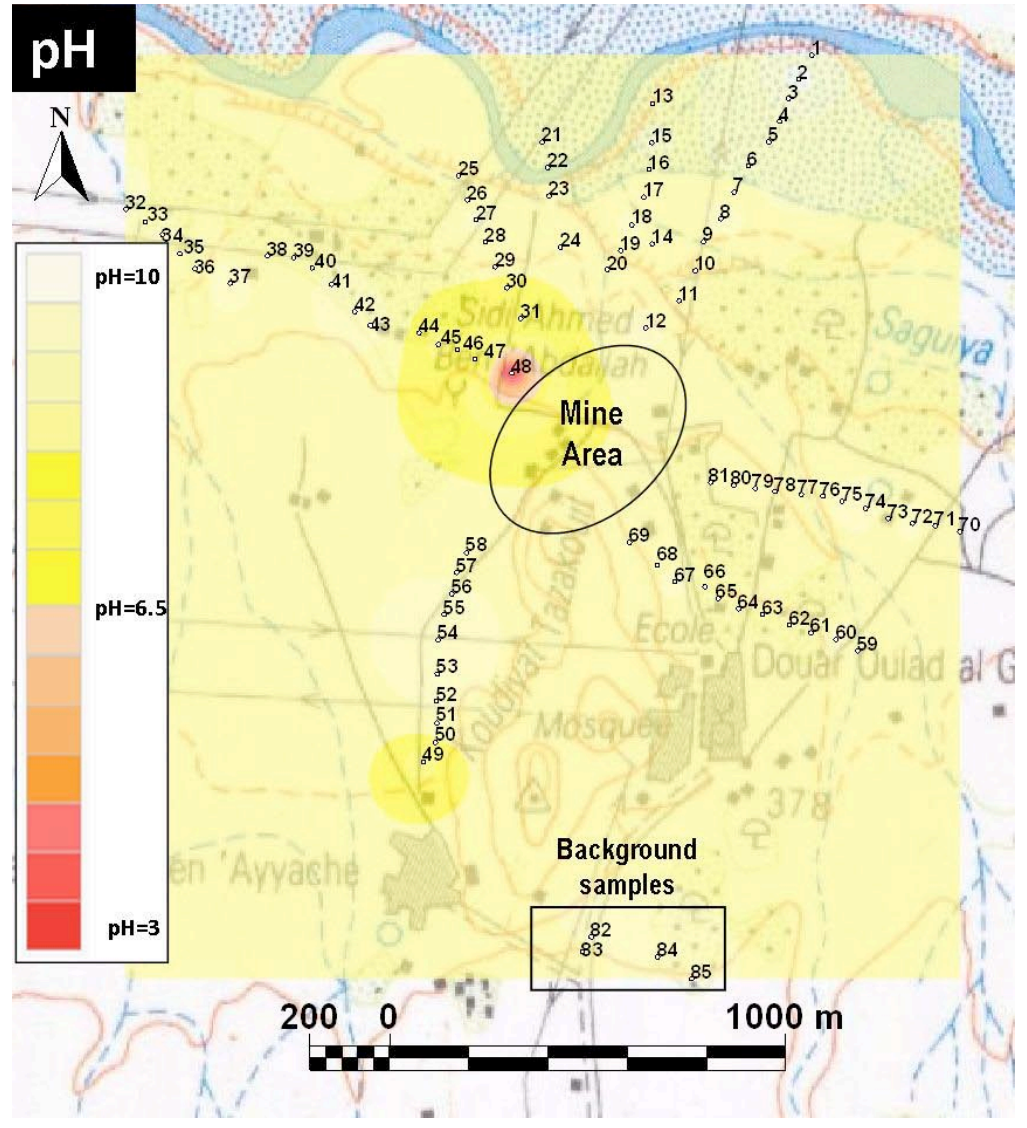

Fig. (2). GIS contour map of $\mathrm{pH}$ at the mine area.

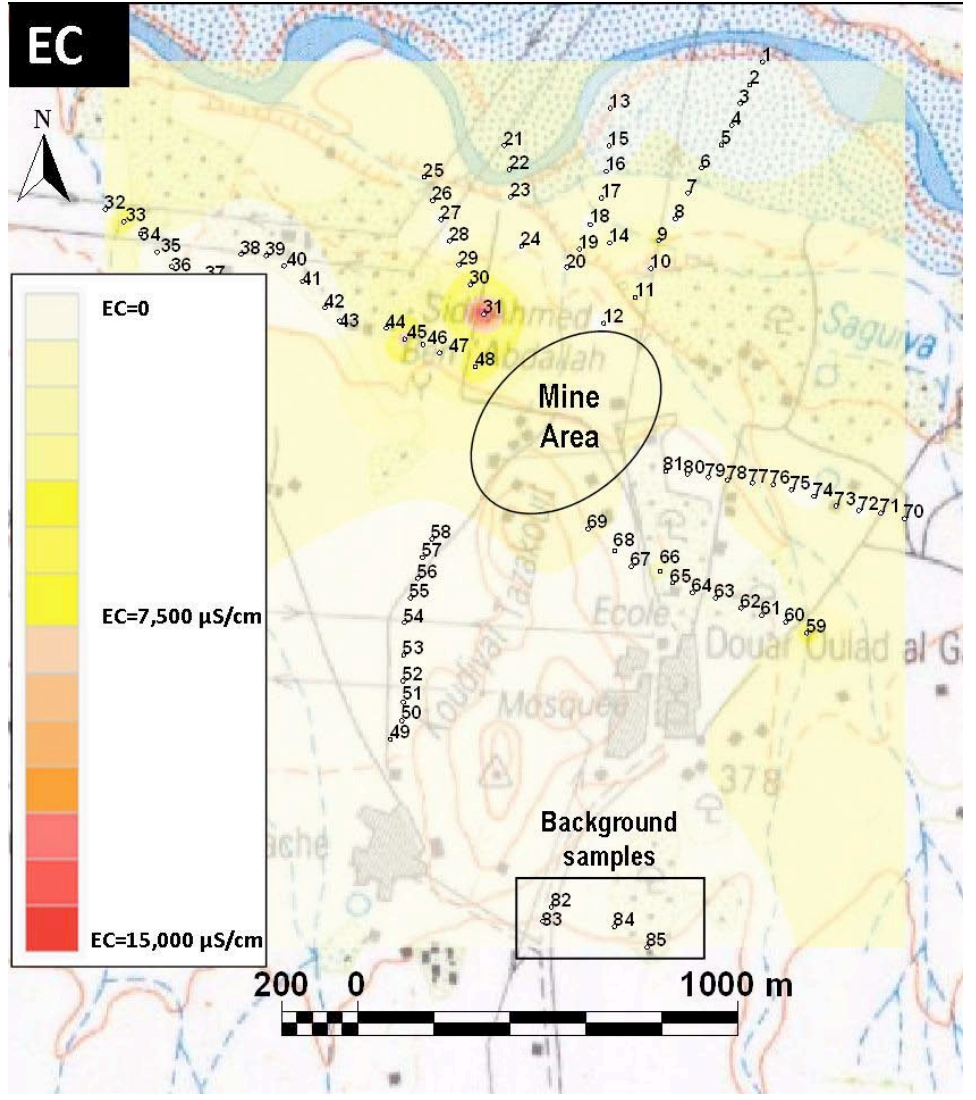

Fig. (3). GIS contour map of the electrical conductivity at the mine area. 


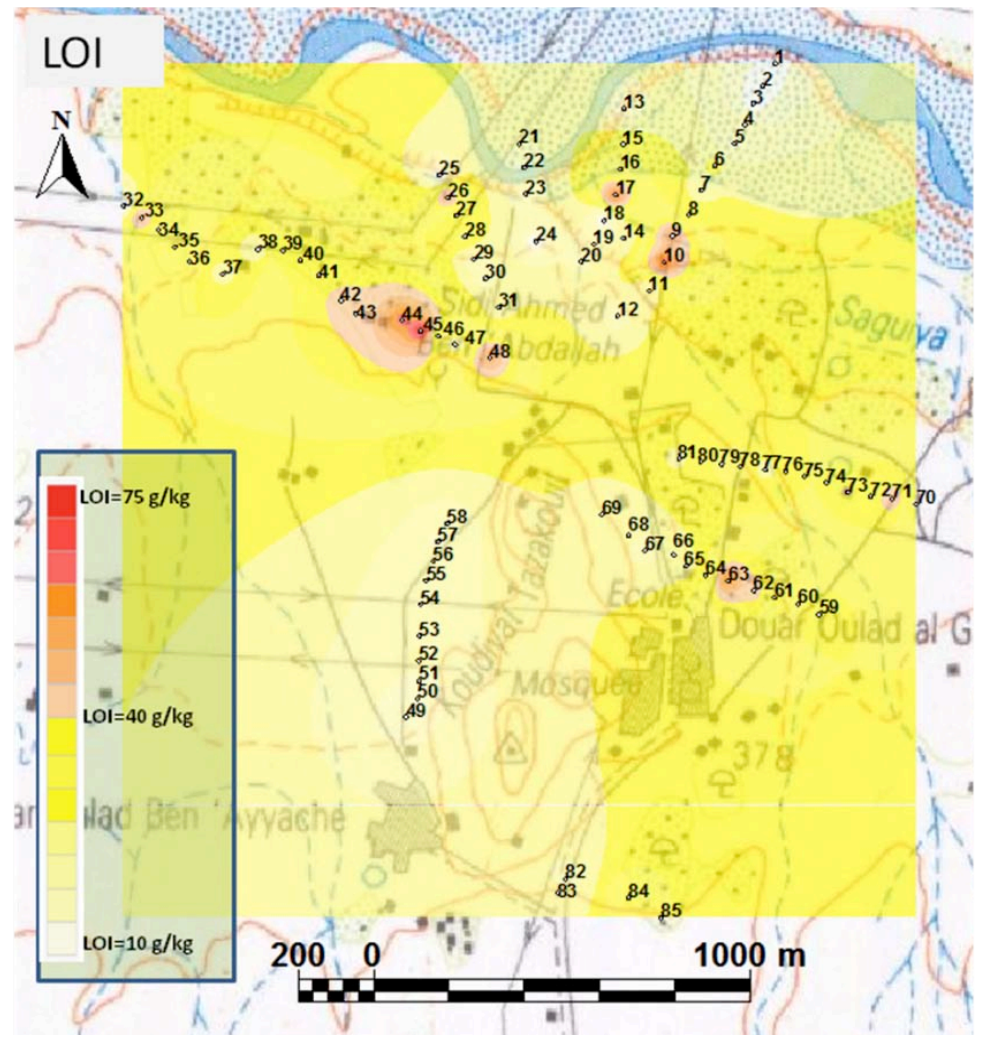

Fig. (4). GIS contour map of the loss on ignition (LOI) at the mine area.

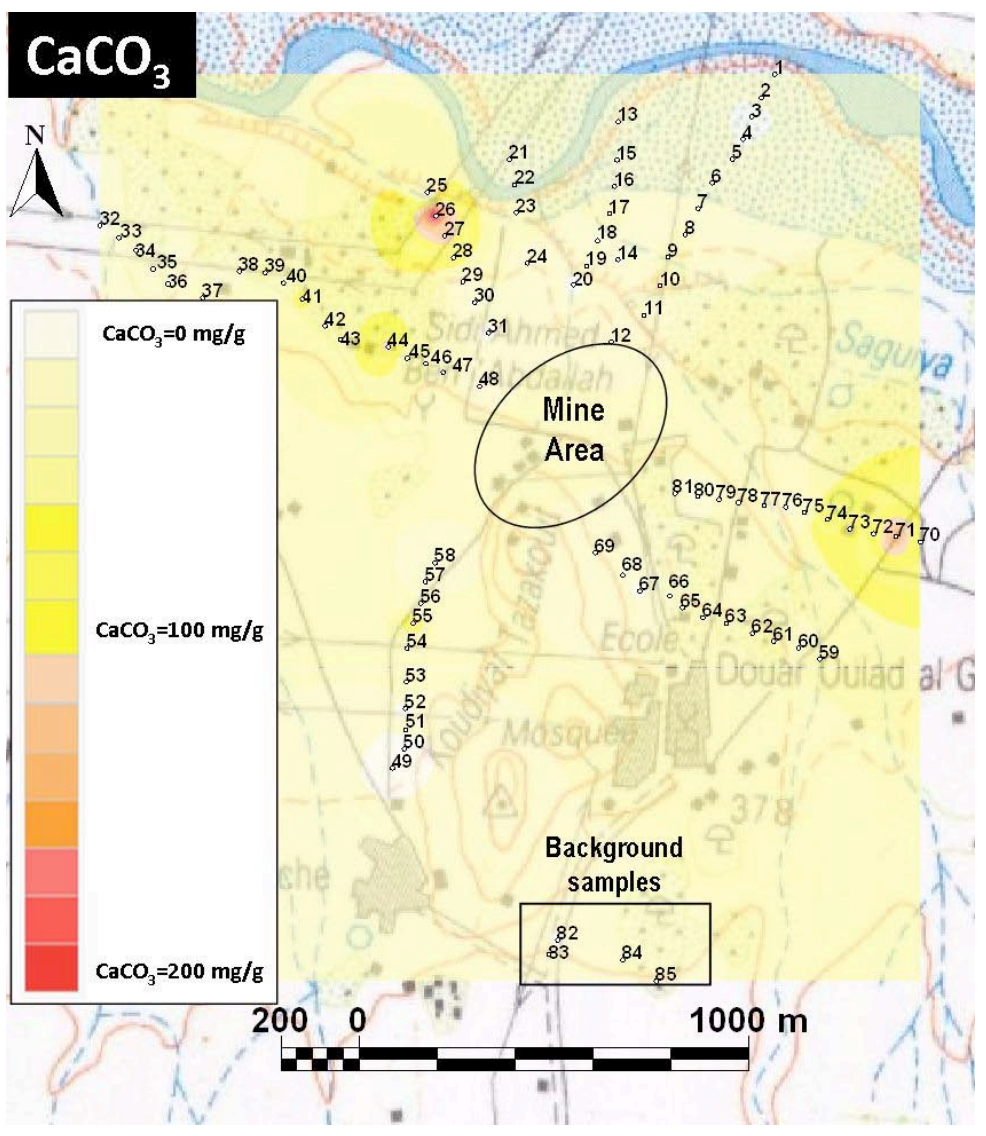

Fig. (5). GIS contour map of the $\mathrm{CaCO}_{3}$ content of the mine area.

13 to $75 \mathrm{~g} / \mathrm{Kg}$, except some points where LOI could reach 76 $\mathrm{g} / \mathrm{kg}$ due to some close localized agricultural activities. The observed carbonate content ranged from 10 to $210 \mathrm{mg} \cdot \mathrm{g}^{-1}$ (Fig. 5), although the majority of the samples present similar 


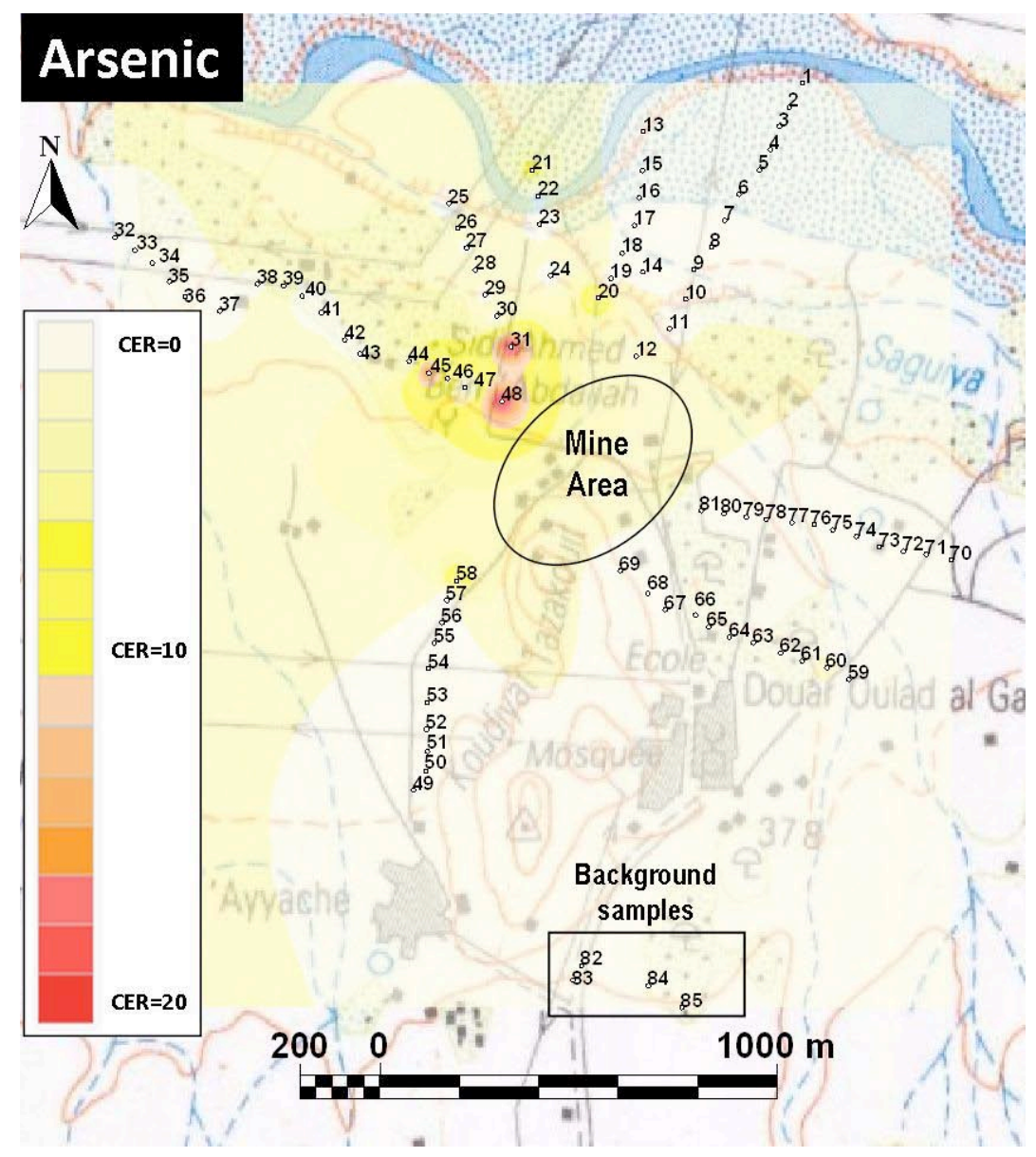

Fig. (6). GIS contour map of arsenic distribution around the mine area.

$\mathrm{CaCO}_{3}$ content to background samples. The highest values are observed for samples D26 and D71, located at $400 \mathrm{~m}$ of the mine. Together with basic $\mathrm{pH}$ values, the presence of carbonates in the soil lead to an increase in the retention of heavy metals, mainly as carbonate salts as a consequence of precipitation, the principal retention mechanism of heavy metals [36].

From the obtained results employing FP-XRF and the corresponding CER values, elements can be classified into pollutants (elements anthropogenically enhanced) or lithogenic elements (those with CER values similar to background samples). In this concern, most of the samples have CER values above 5 for $\mathrm{As}, \mathrm{Cu}, \mathrm{Pb}$ and $\mathrm{Zn}$ (Table S2), thus being considered the main pollutants of the mine area.

Arsenic distribution around the mine area, given in Fig. (6), showed two hot spots located just beside the mine area corresponding to samples D48 (3108 ppm, CER=280) and D31 (203 ppm, CER=19,4). Moving away from this area, samples showed lower As concentration with values similar to background samples, except samples D45 (203 ppm, $\mathrm{CER}=15,9)$ and D46 (125 ppm, CER=9,2). Sample D48 depicts a very high arsenic concentration (more than 100 fold higher than background levels) indicating that remediation is mandatory for this specific area. An anomalous sampling point is represented by sample D21 (72 ppm, $\mathrm{CER}=7,1$ ), proceeding from the other side of the river, with arsenic concentration much higher than samples closer to the mine site. Thus, this area should be under monitoring since it is in contact with the creek waters.

Regarding $\mathrm{Cu}$ CER distribution map along the mining area (Fig. 7) it can be stated that distribution of pollutants followed a similar trend as As although in a lesser degree of pollution. Thus, the highest polluted samples are those located close to the mine, such as samples D20 (80 ppm, $\mathrm{CER}=2.6)$, D48 (144 ppm, CER=5.9) and D45 (173 ppm, $\mathrm{CER}=5.1)$. Again, sample D21 (51 ppm, CER=1.9) at the river basin, has a relatively high copper concentration despite being far from the mine area. Also, the area close to Koudiyat Tazakourt hill, present copper concentration similar to background samples, thus indicating no anthropogenic contribution with copper. The lead distribution around the mine (Fig. 8) showed 4 hot spots located around samples D31 (180 ppm, CER=13.0), D45 (770 ppm, CER=45.9), D48 (2310 ppm, CER=130) and D58 (420 ppm, CER=30). Sample D21 (62 ppm, CER=4.6) should be also considered due to their high CER values and proximity to creek waters. CER distribution map for $\mathrm{Zn}$ (Fig. 9) followed the same trend as $\mathrm{Pb}$ with 4 hot spots located at samples D20 (630 ppm, CER=8.5), D45 (1110 ppm, CER=13.6), D48 (30 ppm, $\mathrm{CER}=10.8)$ and $\mathrm{D} 58$ (930 ppm, $\mathrm{CER}=10.8)$.

Generally, GIS contour maps of CER for the pollutants showed the most contaminated at the vicinity of the mine, especially at the northwest area, probably linked to weathering effects and topography of the area. 


\section{Copper}
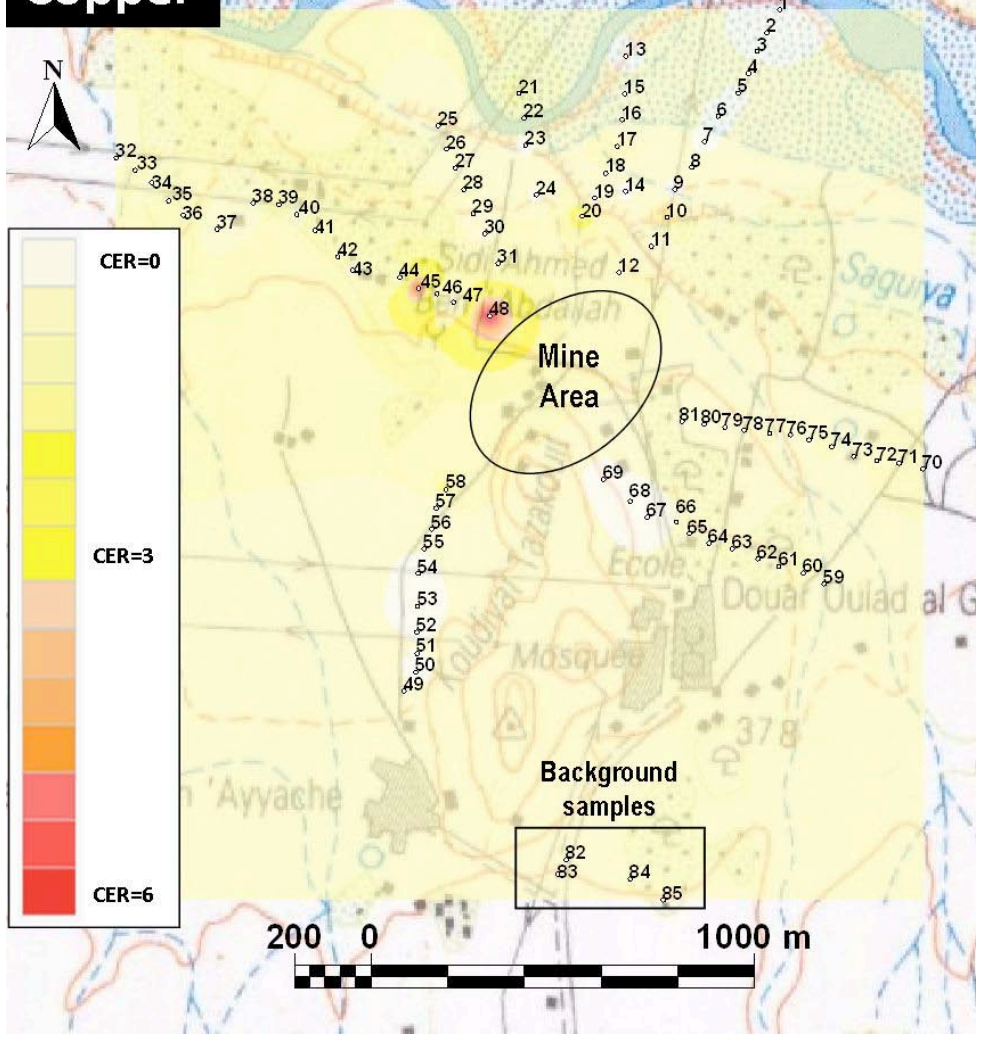

Fig. (7). GIS contour map of copper distribution around the mine area.

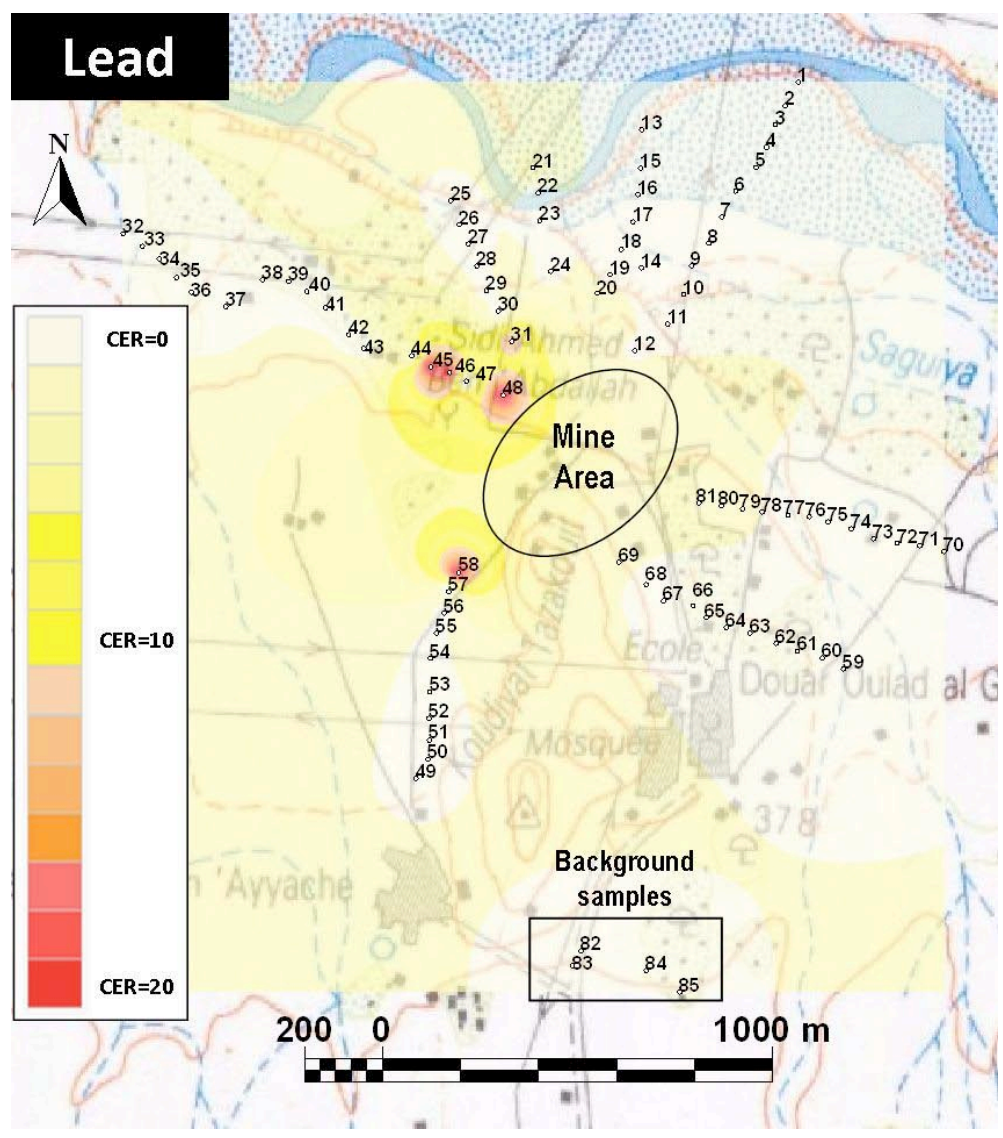

Fig. (8). GIS contour map of lead distribution around the mine area. 
In addition to the GIS treatment, a conventional PCA analysis was carried out resulting on $\mathrm{PC} 1$ and $\mathrm{PC} 2$ to explain around the $80 \%$ of the total variance, being PC1 $(65 \%$ of total variance) loaded by heavy metal $\mathrm{CER}$ values, $\mathrm{pH}$ and Electrical Conductivity (EC) and PC2 (13\% of total variance) loaded with LOI (loss on ignition) and Carbonate concentration. These results confirmed the expected good correlation between $\mathrm{pH}, \mathrm{EC}$ and heavy metal CER values.

Other elements measured by FP-XRF presented values close to background samples and, accordingly. a mean CER

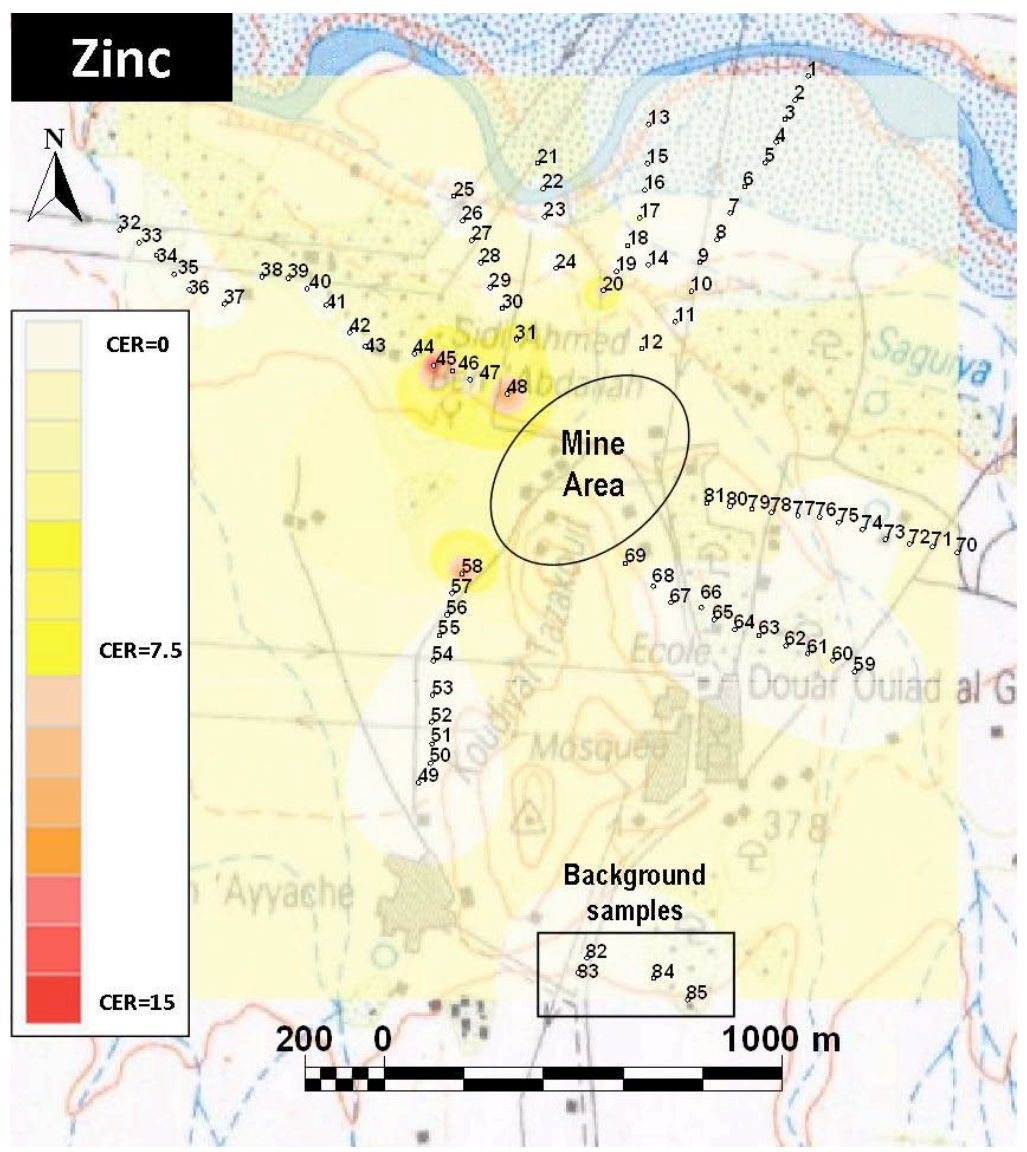

Fig. (9). GIS contour map of zinc distribution around the mine area.

Table 2. Minimum, Maximum and Mean Concentration and CER Values for the Lithogenic Elements in Mine Area and Background Samples

\begin{tabular}{|c|c|c|c|c|c|c|c|}
\hline & & \multicolumn{3}{|c|}{ Mine Area Samples } & \multicolumn{3}{|c|}{ Background Samples } \\
\hline & & Min & Max & Mean & Min & Max & Mean \\
\hline $\mathrm{Ba}$ & Conc. & 221.5 & 541 (D17) & $389 \pm 70$ & 404 & 530 & $449 \pm 60$ \\
\hline \multirow{2}{*}{$\mathrm{Fe}$} & Conc. & 19632 & 121652 (D48) & $32721 \pm 10000$ & 30769 & 38106 & $35555 \pm 3000$ \\
\hline & CER & 0.4 & 4.8 & $0.9 \pm 0.5$ & 0.9 & 1.1 & $1.0 \pm 0.1$ \\
\hline $\mathrm{K}$ & CER & 0.3 & 1.4 & $0.8 \pm 0.3$ & 0.9 & 1.1 & $1.0 \pm 0.1$ \\
\hline \multirow{2}{*}{$\mathrm{Mn}$} & Conc. & 290 & 1119 (D21) & $607 \pm 150$ & 631 & 737 & $699 \pm 50$ \\
\hline & CER & 0.4 & 2.0 & $0.9 \pm 0.3$ & 0.9 & 1.0 & $1.0 \pm 0.1$ \\
\hline \multirow{2}{*}{$\mathrm{Rb}$} & Conc. & 47 & 106 (D10) & $76 \pm 13$ & 73.4 & 86.4 & $81 \pm 6$ \\
\hline & CER & 0.5 & 1.7 & $1.0 \pm 0.3$ & 0.9 & 1.1 & $1.0 \pm 0.1$ \\
\hline $\mathrm{Ti}$ & CER & 0.4 & 1.3 & $0.9 \pm 0.2$ & 0.9 & 1.1 & $1.0 \pm 0.1$ \\
\hline $\mathrm{Zr}$ & Conc. & 112 & 335 (D67) & $215 \pm 50$ & 199 & 235 & $210 \pm 17$ \\
\hline
\end{tabular}

Conc. is given in $\mathrm{mg} / \mathrm{kg}$. Max concentration is in parenthesis. 
value lower than 2 , thus considering their origin as lithogenic. The values obtained for $\mathrm{Ba}, \mathrm{Fe}, \mathrm{K}, \mathrm{Rb}, \mathrm{Sr}$, Ti and $\mathrm{Zr}$ are shown on Table 2.

As seen from the results on Table 2, mean values of mine area samples are similar to those of background samples and, in addition, mean CER values are between 0 and 2 (excepting sample 48 with high Fe content and sample 26 with high Sr content), thus indicating no anthropogenic enhancement of these elements in the soils analyzed.

Finally, other elements were detected at extremely high concentration in some samples. High sulphur concentrations were found in samples D19 (18400 ppm), D31 (14500 ppm), D33 (15500 ppm), D45 (36800 ppm), D48 (113700 ppm), D58 (5300 ppm), D59 (14800 ppm) and D70 (32400 ppm). High arsenic concentrations are also found in some of these samples supporting the consideration of the arseno-pyrite nature of the mineral ores. Other elements such as $\mathrm{Ag}, \mathrm{Au}$, $\mathrm{Bi}, \mathrm{Br}, \mathrm{Cd}, \mathrm{Co}, \mathrm{Cr}, \mathrm{Ni}, \mathrm{P}, \mathrm{Sb}$ or Se were not detected due to the limits of detection of the FP-XRF.

For the mobility and particle size effect studies, 7 samples were selected due to their high content on pollutants (samples D20, D31, D46, D48, D58 and D70) or for their spatial significance (sample at the other side of the river creek, D21). Results obtained along with some drinking water quality standards, are depicted in Table $\mathbf{3}$.

Results given in Table $\mathbf{3}$, indicate an increase on both As and $\mathrm{Pb}$ concentration when the samples are milled and sieved below $100 \mu \mathrm{m}$, i.e., samples D20 (from 125 to 167 ppm), D31 (from 203 to 268 ppm), D46 (from 125 to 172 ppm), D48 (from 3108 to $3569 \mathrm{ppm}$ ) and D58 (from 113 to $149 \mathrm{ppm}$ ) had an enrichment on As and also for $\mathrm{Pb}$ samples D31 (from 180 to $313 \mathrm{ppm}$ ), D46 (from 375 to $477 \mathrm{ppm}$ ) and D48 (from 2309 to $2614 \mathrm{ppm}$ ) showed an enrichment when milled and sieved. On the rest of samples, slight differences were found. Thus, it can be stated that, in general, these elements are forming part of the particle core which is in agreement of the arseno-pyrite nature of the mineral ore. The trend followed for $\mathrm{Cu}$ is a diminution of the concentration as the soil is being milled indicating that instead of forming part of the mineral, $\mathrm{Cu}$ is adsorbed at the surface of the soil particles thus indicating and anthropogenic origin. A few exceptions are found such as samples D31 (from 43 to $77 \mathrm{ppm}$ ), D48 (from 144 to $167 \mathrm{ppm}$ ), D70 (from 33 to 50 ppm) which, in these cases, may constitute part of the arseno-pyrite mineral ore. For zinc, slightly higher concentrations are found when diminishing the particle size of the soil that support its presence forming part of the mineral ores.

Regarding the results obtained for the mobility of selected samples, collected in Table $\mathbf{3}$, it can be stated that the content of arsenic, lead and zinc of some samples is higher than the quality standard regulations while $\mathrm{Cu}$ concentration on the mobile phase is bordering quality standards. Despite being the most acidic sample $(\mathrm{pH}=3.5)$, with high $\mathrm{EC}(\mathrm{EC}=4873 \mu \mathrm{S} / \mathrm{cm})$ and low $\mathrm{CaCO}_{3}$ content $(25,8 \mathrm{mg} / \mathrm{g})$, the most polluted sample (D48) did not present high metal content on the mobile phase, thus indicating less danger than expected when taking into account only total concentration values. According to literature [37] these conditions favor availability of cations, but sample D48 has also a high LOI value which benefits the adsorption of labile ions at the soil which explains the relatively low mobility of sample D48. The sample presenting most mobility of pollutants is sample D46, which is a soil sample alkaline $(\mathrm{pH}=8.1)$, with an $\mathrm{EC}$ of $2151 \mathrm{uS} / \mathrm{cm}, \mathrm{CaCO}_{3}$ content of 58.4 $\mathrm{mg} / \mathrm{g}$ and a LOI of $39.3 \mathrm{~g} / \mathrm{kg}$. In these conditions mobility is not favored but the relatively low value of LOI regarding sample D48 enable the availability of cations from the mine ore to the mobile phase. Therefore, it can be stated that the physico-chemical parameters analyzed does not correlate with the mobility results, thus, to assess the toxicological risk of the Draa Lasfar mine area additional specific measurements are required.

The analysis of results reveals both the mine site and related residues to be the main contributors to the observed pollution. In addition and since the mobility of contaminants

Table 3. Results for $<2 \mathbf{m m}$ and $<\mathbf{1 0 0} \mu \mathrm{m}$ Particle Size and Fraction of Metal Mobile

\begin{tabular}{|c|c|c|c|c|c|c|c|c|c|c|c|c|}
\hline & \multicolumn{3}{|c|}{ As } & \multicolumn{3}{|c|}{$\mathrm{Cu}$} & \multicolumn{3}{|c|}{$\mathbf{P b}$} & \multicolumn{3}{|c|}{ Zn } \\
\hline & $\begin{array}{c}2 \mathrm{~mm} \\
(\mathrm{mg} / \mathrm{kg})\end{array}$ & $\begin{array}{c}100 \mu \mathrm{m} \\
(\mathrm{mg} / \mathrm{kg})\end{array}$ & $\begin{array}{c}\text { Mob. } \\
(\mathrm{mg} / \mathrm{L})\end{array}$ & $\begin{array}{c}2 \mathrm{~mm} \\
(\mathrm{mg} / \mathrm{kg})\end{array}$ & $\begin{array}{c}100 \mu \mathrm{m} \\
(\mathrm{mg} / \mathrm{kg})\end{array}$ & $\begin{array}{c}\text { Mob. } \\
\text { (mg/L) }\end{array}$ & $\begin{array}{c}2 \mathrm{~mm} \\
(\mathrm{mg} / \mathrm{kg})\end{array}$ & $\begin{array}{c}100 \mu \mathrm{m} \\
(\mathrm{mg} / \mathrm{kg})\end{array}$ & $\begin{array}{c}\text { Mob. } \\
\text { (mg/L) }\end{array}$ & $\begin{array}{c}2 \mathrm{~mm} \\
(\mathrm{mg} / \mathrm{kg})\end{array}$ & $\begin{array}{c}100 \mu \mathrm{m} \\
(\mathrm{mg} / \mathrm{kg})\end{array}$ & $\begin{array}{c}\text { Mob. } \\
\text { (mg/L) }\end{array}$ \\
\hline D20 & 125 & 167 & BDL & 80 & 72 & BDL & 55 & 66 & BDL & 628 & 713 & BDL \\
\hline D21 & 72 & 67 & BDL & 51 & 48 & BDL & 62 & 61 & BDL & 144 & 150 & BDL \\
\hline D31 & 203 & 268 & 49 & 43 & 77 & 2 & 180 & 313 & 6 & 481 & 734 & 18 \\
\hline D46 & 125 & 172 & 54 & 60 & 59 & 1 & 375 & 477 & 17 & 774 & 933 & 23 \\
\hline D48 & 3108 & 3569 & 5 & 144 & 167 & 1 & 2309 & 2614 & BDL & 631 & 704 & 4 \\
\hline D58 & 113 & 149 & BDL & 71 & 77 & BDL & 425 & 537 & BDL & 925 & 1087 & BDL \\
\hline D70 & 15 & 15 & 29 & 33 & 50 & BDL & 24 & 20 & BDL & 97 & 91 & BDL \\
\hline MAROC $^{A}$ & - & - & 0.05 & - & - & 2.0 & - & - & 0,05 & - & - & 5 \\
\hline $\mathbf{U S ~ E P A}^{\mathbf{B}}$ & - & - & 0.01 & - & - & 1,3 & - & - & 0.015 & - & - & 5 \\
\hline WHO $^{\mathrm{C}}$ & - & - & 0.01 & - & - & 2.0 & - & - & 0.01 & - & - & 5 \\
\hline
\end{tabular}

A- http://www.minenv.gov.ma/index.asp?param=2_cadre juridique/normes.htm

B- Guidelines for drinking water quality. http://www.epa.gov/safewater/contaminants/index.html\#7

C- WHO http://www.who.int/water sanitation health/dwq/GDW8rev1 and2.pdf 
is low, the manipulation of mineral ore is considered to be minimum at the mining site, so, mineral processing was carried out outside of the mining site.

\section{CONCLUSIONS}

Draa Lasfar mine area has been characterized by determining various physico-chemical parameters of edaphological importance, including $\mathrm{pH}$, electrical conductivity (CE), $\mathrm{CaCO}_{3}$ content and loss on ignition (LOI). Anthropogenic pollution has been assessed by the use of CER. Thus, As, $\mathrm{Cu}, \mathrm{Pb}$ and $\mathrm{Zn}$ can be distinguished as the main pollutants of the mine area. CER values obtained for $\mathrm{Ba}, \mathrm{Fe}, \mathrm{K}, \mathrm{Rb}, \mathrm{Sr}, \mathrm{Ti}$ indicated its lithogenic characteristic. GIS contour maps of pollutants using CER data have been a valuable tool to characterize pollutants distribution around the mine area and determine sources of contamination. GIS maps showed a similar distribution for $\mathrm{As}$ and $\mathrm{Cu}$, as well as for $\mathrm{Pb}$ and $\mathrm{Zn}$. The most contaminated sites were at the vicinity of the mine site, especially at the northwest area, probably linked to weathering effects and topography of the area. No contamination was found in and around Koudiyat Tazakourt hill. Concerning mobility studies, $\mathrm{As}, \mathrm{Pb}$ and $\mathrm{Zn}$ concentration in some samples exceeded water quality standard regulations while $\mathrm{Cu}$ concentration on the mobile phase is on the border. Nevertheless, the most polluted samples did not present high metal content on the mobile phase, thus indicating lower risk than expected when taking into account only total concentration values.

\section{CONFLICT OF INTEREST}

None declared.

\section{ACKNOWLEDGEMENTS}

The present work has been carried with support of the Spanish Ministry of Science and Innovation (Grant CTQ2009-07432), the Morocco-Spanish AECID project $\mathrm{N}^{\circ}$ $\mathrm{A} / 011433 / 07$ and the pole of competences on Water and Environment (Morocco).

\section{SUPPLEMENTARY MATERIAL}

Supplementary material is available on the publishers Web site along with the published article.

\section{REFERENCES}

[1] Adriano DC. Trace elements in the terrestrial environment. Springer Verlag, New York, U.S. 1986.

[2] Osan J, Kurunczi S, Török S, Van Grieken R. X-Ray analysis of riverbank sediment of the Tisza (Hungary): identification of particles from a mine pollution event. Spectrochim Acta 2002; Part B 57: 413-22.

[3] El Adnani M, Rodriguez-Maroto JM, Sbai ML, Loukili IL, Nejmeddine A. Impact of polymetallic mine $(\mathrm{Zn}, \mathrm{Pb}, \mathrm{Cu})$ residues on surface water, sediments and soils at the vicinity (Marrakech, Morocco). Environ Technol 2007; 28: 969-85.

[4] Ferguson C, Kasamas H. Risk assessment for contaminated sites in Europe. LQM Press University of Nottingham, Nottingham, U.K. 1999.

[5] Kalnicky DJ, Singhvi R. Field portable XRF analysis of environmental samples. J Hazard Mater 2001; 83: 93-122.
[6] Kilbride C, Poole J, Hutchings TR. A comparison of $\mathrm{Cu}, \mathrm{Pb}$, As, $\mathrm{Cd}, \mathrm{Zn}, \mathrm{Fe}, \mathrm{Ni}$ and $\mathrm{Mn}$ determined by acid extraction/ICP-OES and ex situ field portable X-ray fluorescence analyses. Environ Pollut 2006; 143: 16-20.

[7] Harper M, Pacolay B, Hintz P, Andrew ME. A comparison of portable XRF and ICP-OES analysis for lead on air filter samples from a lead ore concentrator mill and a lead-acid battery recycler. J Environ Monit 2006; 8: 384-92.

[8] Argyraki A, Ramsey MH, Potts PJ. Evaluation of portable x-ray fluorescence instrumentation for in situ measurements of lead on contaminated land. Analyst 1997; 122: 743-9.

[9] Zhai L, Liao X, Chen T, et al. Regional assessment of cadmium pollution in agricultural lands and the potential health risk related to intensive mining activities: A case study in Chenzhou City, China. J Environ Sci 2008; 20: 696-703.

[10] Carr R, Zhang C, Moles N, Harder M. Identification and mapping of heavy metal pollution in soils of a sports ground in Galway City, Ireland, using a portable XRF analyser and GIS. Environ Geochem Health 2008; 30: 45-52.

[11] Franco C, Soares A, Delgado J. Geostatistical modelling of heavy metal contamination in the topsoil of Guadiamar river margins ( $S$ Spain) using a stochastic simulation technique. Geoderma 2006; 136: 852-64

[12] Sutherland RA, Tolosa CA. Multi-element analysis of roaddeposited sediment in an urban drainage basin, Honolulu, Hawaii. Environ Pollut 2000; 110: 483-95.

[13] Bhuiyana MAH, Parvezb L, Islamc MA, Dampared SB, Suzukia S. Heavy metal pollution of coal mine-affected agricultural soils in the northern part of Bangladesh. J Hazard Mater 2010; 173: 38492.

[14] Reimann C, Filzmoser P, Garrett RG. Background and threshold: critical comparison of methods of determination. Sci Total Environ 2005; 46: 1-6.

[15] Bourennane H, Douay F, Sterckeman T, et al. Mapping of anthropogenic trace elements inputs in agricultural topsoil from Northern France using enrichment factors. Geoderma 2010; 157: 165-74.

[16] Kersten M, Förstner U. Trace element speciation: analytical methods and problems, ed G.E., Batley, CRC Press, Florida 1995; 245-317.

[17] Tessier A, Campbell PGC, Bisson M. Sequential extraction procedures for the speciation of particulate trace metals. Anal Chem 1979; 51: 844-51.

[18] Kennedy VH, Sanchez AL, Oughton DH, Rowland AP. Use of single and sequential chemical extractants to assess radionuclide and heavy metal availability from soils for root uptake. Analyst 1997; 122: 89-100.

[19] Rauret G, López-Sánchez J, Sahuquillo F, Muntau AH, Quevauviller P. Indicative values for extractable contents (mass fractions) of $\mathrm{Cd}, \mathrm{Cr}, \mathrm{Cu}, \mathrm{Ni}, \mathrm{Pb}$ and $\mathrm{Zn}$ in sediment (CRM 601) following the modified BCR-sequential extraction (three-step) procedure - Addendum to EUR-report 17554 EN. Belgium: European Commission. BCR Information Reference Materials, EUR 19502 EN 2000.

[20] Sahuquillo A, Rigol A, Rauret G. Overview of the use of leaching/extraction tests for risk assessment of trace metals in contaminated soils and sediments. Trends Anal Chem 2003; 22: $152-9$.

[21] Moreno-Jimenez E, Peñalosa JM, Manzano R, Carpena-Ruiz RO, Gamarra R, Esteban E. Heavy metals distribution in soils surrounding an abandoned mine in NW Madrid (Spain) and their transference to wild flora. J Hazard Mater 2009; 162: 854-9.

[22] El Gharmali A, Rada A, El Adnani M, Tahlil N, El Meray M, Nejmeddine A. Impact of acid mine drainage on the quality of superficial Waters and sediments in the Marrakesh region, Morocco. Environ Technol 2004; 25: 1431-42.

[23] Ministère de l'énergie et des mines. Délégation Régionale de Marrakech 1996. Monographie de la province de Marrakech (Géologie, Mines, Energie). Available at: [www.minenv.gov.ma/onem/synt_monog_locales/mono_loc_marra kech.pdf]. [updated and cited 2010 November 1].

[24] Marcoux E, Belkabir A, Gibson HL, Lentz D, Ruffet G. Draa Sfar, Morocco: A Visean $(331 \mathrm{Ma})$ pyrrhotite-rich, polymetallic volcanogenic massive sulphide deposit in a Hercynian sedimentdominant terrane. Ore Geol Rev 2008; 33: 307-28. 
[25] Aubert G. Méthodes d'analyses des sols. C.R.D.P., Marseille, 1978; 80-83: 123-7.

[26] Pérez G, López-Mesas M, Valiente M. Assessment of heavy metal remobilization by fractionation: comparison of leaching tests applied to roadside sediments. Environ Sci Technol 2008; 42: 2309-15.

[27] Petersen GW, Bell JC, Mcsweeney K, et al. Geographic information systems in agronomy. Adv Agron 1995; 55: 67-111.

[28] Lahr J, Kooistra L. Environmental risk mapping of pollutants: State of the art and communication aspects. Sci Total Environ 2010; 408: 3899-907.

[29] Franco C, Soares A, Delgado J. Geostatistical modelling of heavy metal contamination in the topsoil of Guadiamar river margins (S Spain) using a stochastic simulation technique. Geoderma 2006; 136: 852-64.

[30] Pons X. MIRAMON Available at: [http://www.creaf.uab.es/ miramon] (updated and cited 19 April 2010).

[31] Shi W, Liu J, Du Z, Song Y, Chen C, Yue T. Surface modelling of soil pH. Geoderma 2009; 150: 113-9.
[32] Panagopoulos T, Jesus J, Antunes MDC, Beltrao J. Analysis of spatial interpolation for optimising management of a salinized field cultivated with lettuce. Eur J Agron 2006; $24: 1$.

[33] Jongman RHG, Ter Braak CJF, Van Tongeren OFR. Data analysis in community and landscape ecology, Cambridge University Press, Cambridge, U.K. 1995.

[34] de Matos AT, Fontes MPF, da Costa LM, Martínez MA. Mobility of heavy metals as related to soil chemical and mineralogical characteristics of Brazilian soils. Environ Pollut 2001; 111: 429-35.

[35] El Hachimi ML, El Founti L, Bouabdli A, Saidi N, Fekhoui M, Tasse $\mathrm{N} . \mathrm{Pb}$ and $\mathrm{As}$ in mining alkaline waters: contamination, comportment and risks (the Zeida abandoned mine, Morocco). Rev Sci Eau 2007; 20: 1-13.

[36] Plassard F, Winiarski T, Petit-Ramel M. Retention and distribution of three heavy metals in a carbonated soil: comparison between batch and unsaturated column studies. J Contam Hydrol 2000; 42: 99-111.

[37] Chuan MC, Shu GY, Liu JC. Solubility of heavy metals in a contaminated soils: effect of redox potential and $\mathrm{pH}$. Water Air Soil Pollut 1996; 90: 543-56.

Received: May 26, 2011

(C) Avila et al.; Licensee Bentham Open.

This is an open access article licensed under the terms of the Creative Commons Attribution Non-Commercial License (http://creativecommons.org/licenses/by$\mathrm{nc} / 3.0 /$ ), which permits unrestricted, non-commercial use, distribution and reproduction in any medium, provided the work is properly cited. 